\title{
ISOLATION AND PURIFICATION OF DNA FROM MASS CULTURES OF THE FREE-LIVING AMOEBA
}

by

\author{
CARL T. FRIZ
}

Department of Anatomy, The University of British Columbia

Vancouver, Canada V6T 1W5

Keywords: Amoeba proteus, Chaos carolinensis, Polychaos dubia, DNA isolation and purification, RNA contamination, protein contamination, density gradient centrifugation

\begin{abstract}
A method is described for the isolation of a purified, highly polymerized DNA from the free-living amoeba. Proteinase K, RNase T1, RNase (Aspergillus clavatus), phenol extraction, and density gradient centrifugations are important steps in obtaining satisfactory DNA recoveries. The DNA preparations contained no protein and were slightly contaminated with RNA (orcinol-positive material). Since about $70 \%$ of the orcinol-positive material was not affected by $\mathrm{KOH}$ treatment and since only a small amount of it remained after DNase treatment, it is suggested that the most of the orcinol-positive material is not RNA but is some structural carbohydrate. The high degree of polymerization of the isolated DNA was estimated by comparing its buoyant density in CsCl with those found previously for nuclear DNA.
\end{abstract}

\section{INTRODUCTION}

DNA has not been successfully isolated from mass cultures of the free-living amoeba undoubtedly because they have very small DNA/ RNA and DNA/protein ratios (10) and contain potent nucleases (18). MANDEL (18) made numerous attempts to isolate DNA from Amoeba proteus, but could not obtain a highly polymerized product. Over the past 20 years, FRIZ (unpublished data) has attempted to isolate the DNA of these organisms by published methods $(3,4,6,8,9,15,16,19,22,24)$ but has been unsuccessful; the best results being a preparation in which the DNA recovery was less than $10 \%$ and the DNA/RNA and DNA/protein ratios were less than 0.4 and 0.25 , respectively.

In search of improved methods that would insure reproducible results in isolation of the DNA from the free-living amoeba, several variations of the above methods were tested and the most promising results in every case were from those which included density gradient centrifugation. Since it is also important to be certain that the DNA isolated from the amoeba is derived from its genome, density gradient centrifugation is an advantageous addition to the isolation procedure because it not only separates DNA from RNA and protein, but also concentrates and separates the various DNAs according to their buoyant densities.

Therefore, the density gradient centrifugation step is the heart of the procedure reported herein. Although, even with this step, the DNA recovery was somewhat lower than those obtained on

Abbreviations: EDTA = Ethylenediamine tetraacetic acid, K-salt; poly $(\mathrm{dA})$-poly $(\mathrm{dT})=$ polydeoxyadenylic $\times$ polydeoxythymidylic acid, Na-salt; Tris = tris-(hydroxymethyl) aminomethane. 
Tetrahymena $(3,15)$, paramecium (3), Trichomonas (15) and Acanthamoeba (1), this is due to the composition of the free-living amoeba since the above methods when tried on these amoeba gave DNA recoveries much lower than those obtained in this report. This, along with the fact that there was no protein contamination and little, if any, RNA contamination of the final product indicates that the method described below is the best available method for isolating a pure highly polymerized DNA from mass cultures of the free-living amoeba.

\section{MATERIALS AND METHODS}

2.1. Species of amoeba and culture methods

The following species of the free-living amoeba were used in this study: The B strain of Chaos carolinensis and the A-13 strain of Polychaos dubia obtained from Dr. C. CHAPMAN-ANDRESEN, Univeristy of Copenhagen and the $D$ strain of $A$. proteus obtained from Dr. MURIEL ORD, University of Southampton.

All amoeba were cultured under identical conditions as previously described (11) using a modified Chalkely's medium containing 80 $\mathrm{mg} \mathrm{NaCl}, 4 \mathrm{mg} \mathrm{NaHCO}, 4 \mathrm{mg} \mathrm{KCl}, 8 \mathrm{mg} \mathrm{CaCl}_{2}$ and $1.6 \mathrm{mg} \mathrm{Ca}\left(\mathrm{H}_{2} \mathrm{PO}_{4}\right)_{2} \times \mathrm{H}_{2} \mathrm{O}$ per liter (A. proteus and $\mathrm{P}$. dubia) or a modified Marshall's medium containing $28 \mathrm{mg} \mathrm{CaCl}, 6 \mathrm{mg}$ $\mathrm{MgSO}_{4} \times 7 \mathrm{H}_{2} \mathrm{O}, 2 \mathrm{mg} \mathrm{FeSO}_{4} \times 7 \mathrm{H}_{2} \mathrm{O}, 14 \mathrm{mg}$ $\mathrm{K}_{2} \mathrm{HPO}_{4}$ and $7.5 \mathrm{mg} \mathrm{KH} \mathrm{PO}_{4}$ (C. carolinensis).

All cultures were fed Tetrahymena pyriformis and when they were ready to harvest, they were starved for 10 days with a media change each day of this period. After harvesting, the amoeba were lyophilized and stored in a deep freeze until at least $1 \mathrm{~g}$ of lyophilized amoeba had been collected. The pooled lyophilized samples were mixed thoroughly and 500-600 mg were used as starting material for each isolation.

\subsection{DNA preparation and purification}

1) Five or six hundred mg of lyophilized amoeba were homogenized in a medium containing $2.5 \mathrm{ml} 0.15 \mathrm{M}-\mathrm{KCl}-0.1 \mathrm{M}-\mathrm{EDTA}, \mathrm{pH}$ $8.5 ; 2.5 \mathrm{ml} 0.1 \mathrm{M}-\mathrm{KCl}-0.1 \mathrm{M}-\mathrm{Tris}$ and $250 \mu \mathrm{l}$ $20 \%(\mathrm{w} / \mathrm{v})$ sodium lauroyl sarcosinate. After adding $25 \mathrm{mg}$ Proteinase K (Boehringer-Mannheim), the homogenate was incubated overnight at $37{ }^{\circ} \mathrm{C}$. 2) To the homogenate was added 6 $\mathrm{ml}$ buffer saturated phenol and the resulting suspension stirred for 15 minutes. 3) The suspension was then centrifuged at $40,000 \mathrm{rpm}$ in a Beckman L2-65 preparative centrifuge (type 65 rotor) at $4{ }^{\circ} \mathrm{C}$ for 15 minutes. 4) The aqueous layer was separated from the phenolic and reextracted with buffer saturated phenol. 5) The aqueous layer was again removed and the interfacial layers after the first and second centrifugations pooled. 6) To these pooled layers was added $1.0 \mathrm{ml}$ of the above buffer and $1.0 \mathrm{ml}$ of buffer saturated phenol. 7) After heating at $60{ }^{\circ} \mathrm{C}$ for 20 minutes, the suspension was centrifuged as before and the aqueous layer removed and added to the aqueous layer of the second centrifugation. 8) The combined aqueous layers were reextracted with buffer saturated phenol and after centrifugation the aqueous layer was extracted with ether to remove residual phenol. 9) After adjusting the $\mathrm{pH}$ to 7,100,000 units of $T_{1}$ RNase (BoehringerMannheim) and 25,000 units of RNase from Aspergillus clavatus (Sigma) was added and the resulting mixture incubated at $37^{\circ} \mathrm{C}$ overnight. 10) After RNase digestion, the solution was processed again as in steps $2-8$ and a solution of $\mathrm{CsCl}\left(\mathrm{P}=1.9 \mathrm{~g} / \mathrm{cm}^{3}\right)$ added to obtain a final density of approx. $1.60 \mathrm{~g} / \mathrm{cm}^{3}$ along with a minute quantity of poly (dA)-poly (dT) (Sigma) to serve as a reference DNA. 11) After 120 hours of centrifugation at $44,000 \mathrm{rpm}$ in the Beckman L2-65 preparative centrifuge using the SW 65 rotor, the gradient was fractionated using 9 drops per each fraction. 12) After determining the gradient's DNA distribution, those peaks containing the DNA were pooled and recentrifuged for 120 hours to form a second gradient. 13) After fractionation, again using 9 drops, the DNA peaks were pooled and dialyzed against $0.15 \mathrm{M}-\mathrm{NaCl}-0.015 \mathrm{M}$-sodium citrate overnight. 14) To the dialysate was added 2 volumes of ice cold absolute ethanol and the resulting mixture kept at $-20{ }^{\circ} \mathrm{C}$ overnight. After centrifugation and 2 washings with absolute ethanol, the fibrous DNA was dissolved in citrate buffer and stored over chloroform at $4{ }^{\circ} \mathrm{C}$. 


\subsection{Analytical methods}

\subsubsection{DNA determination}

DNA was determined by the diphenylamine reaction as previously described (12). The diphenylamine was of indicator purity (Fisher) and standard curves were constructed using high purity salmon sperm DNA (Cal Biochem).

\subsection{2. $R N A$ determination}

RNA was determined by the orcinol reaction (20) as modified by ALBAUM and UMBREIT (2). Yeast RNA (Cal Biochem) served as the standard and the orcinol (Eastman Kodak) was of spectrometic grade.

\subsubsection{Protein determination}

The protein content was estimated by the method of LOWRY et al. (17). Bovine serum albumin (Cal Biochem) was used to construct standard curves.

\subsubsection{Determination of buoyant density of DNA peaks}

The buoyant density of the DNA peaks was determined as previously described $(12,13,14)$ except that poly (dA)-poly (dT) (Sigma) was added as a reference DNA at the same time as was the $\mathrm{CsCl}$. The amoeba's DNA density distribution was calculated according to SCHILDKRAUT et al. (21).

\subsection{Tests for purity}

\subsubsection{Alkali liability}

To samples in $0.15 \mathrm{M}-\mathrm{NaCl}-0.015 \mathrm{M}$-sodium citrate was added $\mathrm{KOH}$, so that the final concentration was $0.3 \mathrm{M}$. After incubation overnight at $37^{\circ} \mathrm{C}$, the DNA was dialyzed against the same buffer, and the dialysate analyzed by the diphenylamine and orcinol reactions.

\subsubsection{DNase digestion}

DNA preparations in $0.1 \mathrm{M}-\mathrm{NaCl}-0.1 \mathrm{M}-\mathrm{so}-$ dium acetate $-0.005 \mathrm{M}-\mathrm{MgCl}_{2}$ were incubated overnight at $37^{\circ} \mathrm{C}$ with $500 \mu \mathrm{g} \times \mathrm{ml}^{\prime \prime}$ pancreatic DNase (final concentration). After dialysis, the dialysate was examined by the diphenylamine and orcinol reactions.

\section{RESULTS AND DISCUSSION}

\subsection{DNA recovery}

Since the free-living amoeba cannot be cultured under axenic conditions, it is important to establish that the DNA being isolated is genomic or nuclear in origin and not derived from cytoplasmic structures or contaminating organisms, i.e. food organisms and endosymbionts. In order to eliminate any such contamination of genomic DNA in this study, I have imposed two experimental conditions. The first of these requires that the amoebae be starved for a period of 10 days in order that they do not contain DNA of food organism origin (7), and the second uses density gradient centrifugation so that the genomic DNA can be separated from endosymbiont and mitochondrial DNAs according to their buoyant densities. By pooling those fractions which contain the genomic DNA, not only is there a high degree of purity obtained, but also there is a concentration of the highly polymerized genomic DNA.

As can be seen in Table I, the DNA recovered by the above procedure is considerably lower than that recovered for Tetrahymena spp. (3, 15), Trichomonas spp. (15) and Paramecium spp. (3). However, since it is assumed that the DNA isolated in this study is genomic (vide infra) and that genomic DNA is between 42.5 $-53.5 \%$ of the total DNA of the original sample [calculated from the $0.08 \mathrm{mg} \mathrm{DNA} / \mathrm{amoeba}$ found by COHEN (7) and the 0.043 and 0.034 mg DNA/nucleus found by SPEAR and PRESCOTT (22) and TAUTVYdAs (23) respectively], a more accurate estimate of DNA recovery would be to use the estimated amount of genomic DNA present in the original sample. This was carried out and the results of these calculations are shown in Table I under the percent genomic DNA recovered. These values, albeit in the lower range for $\mathrm{C}$. carolinensis, are generally in agreement with the percent recovery of total DNA found for other protozoan species $(3,15)$.

The main loss of amoeba DNA during isolation occurs because of their very low DNA/pro- 
Table I.

Recovery of DNA from the free-living amoeba at various steps of purification.

\begin{tabular}{|c|c|c|c|}
\hline Purification steps ${ }^{+}$ & Total DNA $(\mu \mathrm{g})$ & $\begin{array}{c}\text { Nuclear or } \\
\text { genomic DNA }(\mu \mathrm{g})\end{array}$ & $\begin{array}{c}\% \text { of DNA recovered } \\
\% \text { total }\end{array}$ \\
\hline
\end{tabular}

1) Step 1
A. proteus
600.0
$288.0^{*}$
C. carolinensis
660.6
$316.8^{*}$
P. dubia
343.8
$165 *$

2) Step 2
A. proteus
187.4
31.2
65.1
C. carolinensis
95.7
14.5
30.2
P. dubia
nd

3) Step 3
A. proteus
128.2
21.4
44.5
C. carolinensis
51.3
7.1
14.8
P. dubia
nd

4) Step 4
A. proteus
110.5
18.4
38.4
C. carolinensis
39.1
5.9
12.3
P. dubia
nd

5) Step 5
A. proteus
66.3
11.1
23.0
C. carolinensis
25.1
3.8
7.9
P. dubia
33.4
9.7
20.2

Step $1=$ original sample with no treatment; Step $2=$ after Proteinase K, RNase and phenol treatment and
$\mathrm{CsCl}$ density gradient centrifugation; Step $3=$ after a 2 nd $\mathrm{CsCl}$ density gradient centrifugation; Step $4=$ after
dialysis; Step $5=$ after alcohol precipitation (see Methods).
* Calculated from the assumption that $48 \%$ of the total DNA was of nuclear origin.

tein ratios (10). Evidence can be seen for this if the DNA recovery from A. proteus is compared to that from $C$. carolinensis at the various purification steps (Table I). As can be seen, the percent recovery was two to three times greater for A. proteus and P. dubia [species containing approximately $50 \%$ of the protein present in C. carolinensis (10)] than it was for $\mathrm{C}$. carolinensis.

In general it has been observed (FRIZ, unpublished data) that approximately $49 \%$ of the total DNA of the free-living amoeba is associated with the protein of the interfacial layer after phenol extraction. While this was decreased with Proteinase $\mathrm{K}$ treatment, a large percent of the total DNA remained bound to the protein in this layer. Although ADAM et al. (1) found with Acanthamoeba spp. that they could remove up to $90 \%$ of the DNA bound to the interfacial layer, their procedure was not successful when used on the free-living amoeba; in fact, I found that it only increased the protein content of the final product (FRIz, unpublished data). However, it was found that one procedure did release about 10 to $15 \%$ of the DNA bound to the interfacial layer. This called for the extraction of the interfacial layer with phenol and buffer, warming the resulting mixture to $60{ }^{\circ} \mathrm{C}$ for 20 minutes, centrifugation and removed of the aqueous layer which contained the released DNA.

Although density gradient centrifugation has been used as a purification step for isolation of DNA of Acanthamoeba (1), very seldom has it been used twice in one isolation method. The logic behind the double use of density gradient centrifugation is twofold. First, and most important, it further concentrates the amoeba's genomic DNA. Since there is a considerable amount 

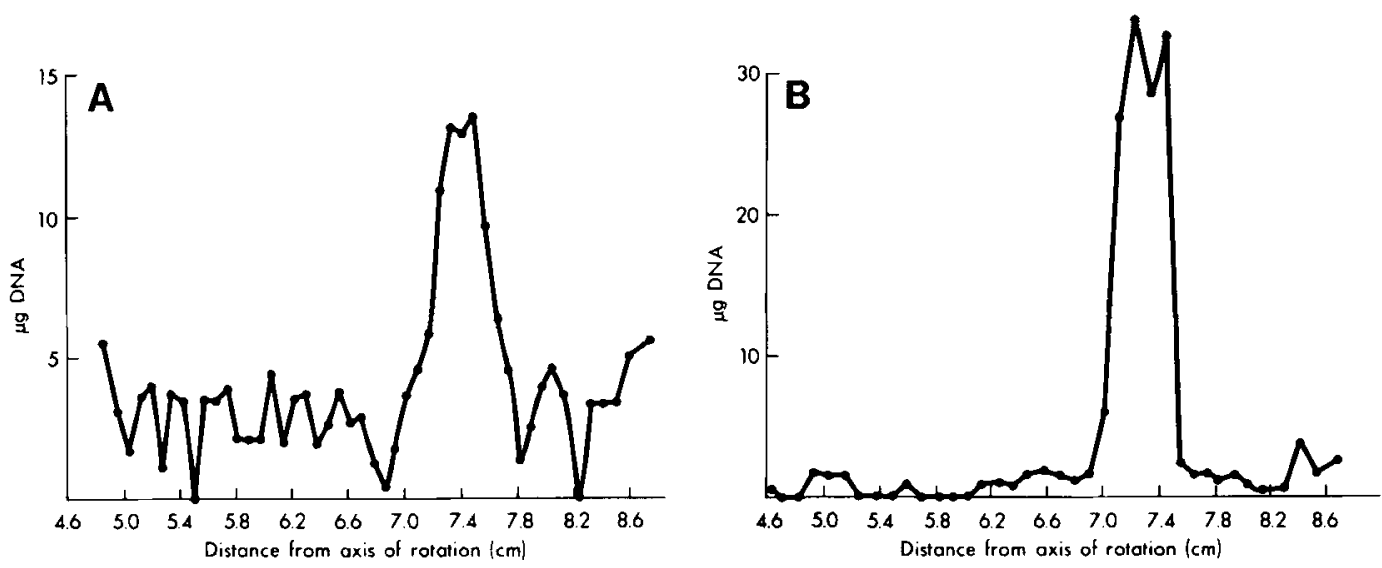

Figure 1. A. A sample of the DNA distribution obtained from one of the three buckets of the preparative centrifuge after centrifugation to equilibrium in $\mathrm{CsCl}$. The main peak DNA is in fractions (13-19) 7.2 to 7.6 $\mathrm{cm}$ from the axis of rotation. B. Fractions 13-19 of A were pooled with similar fractions from the other two buckets after the first density gradient centrifugation and recentrifuged in $\mathrm{CsCl}$. Fraction (12-15) 7.1 to 7.4 $\mathrm{cm}$ from the axis of rotation were pooled and used for dialysis treatment.

of DNA lost with the interfacial layer, concentrating the amount that is extracted into a smaller volume will increase the amount that can be precipitated by ethanol. Secondly, the two centrifugations remove contaminating DNAs that might be present. Figure 1 shows a DNA density distribution after the first and second density gradient centrifugation. As can be seen there is much less contaminating DNAs present in the DNA band after the second centrifugation than after the first.

\subsection{Purity of DNA}

The purity of the DNA preparations in this study are judged on two bases: 1) the degree of contamination of the preparation by DNAs of endosymbionts, contained in all strains and species of the free-living amoeba, or other extraneous DNAs, and 2) the degree of contamination by RNAs and proteins from both amoeba and all other sources.

Since SPEAR and PRESCOTT (22) have shown that $A$. proteus contains three DNA bands upon density gradient centrifugation; two which are genomic or nuclear in origin and band at densities of $1.693 \mathrm{~g} / \mathrm{cm}^{3}$ and $1.714 \mathrm{~g} / \mathrm{cm}^{3}$ whereas the other is cytoplasmic in origin and bands at $1.726 \mathrm{~g} / \mathrm{cm}^{3}$, I have isolated only those DNAs which band at the densities of nuclear DNA. Although this will not guarantee that all the DNA banding in these ranges (1.684 - 1.691 $\mathrm{g} / \mathrm{cm}^{3}$ and $1.705-1.717 \mathrm{~g} / \mathrm{cm}^{3}$ is genomic (degradation of cytoplasmic DNAs could have reduced its density from $1.726 \mathrm{~g} / \mathrm{cm}^{3}$ ), it will greatly increase the probability that the final product is only of genomic origin.

In Table II the results of this study are shown as they relate to the DNA bands of the D strain of $A$. proteus, the B strain of $C$. carolinensis and the A-13 strain of P. dubia. Not only did the DNA bands have the same densities after each centrifugation, but also the same densities for each species; the only difference to be noted being that the main DNA band of P. dubia has the same density as the satellite DNA band of $A$. proteus and $C$. carolinensis, and the main DNA band of $A$. proteus and $C$. carolinensis has the same density as the satellite DNA band of $P$. dubia. These results are also in agreement with the densities obtained by SPEAR and PrescotT (22) and by FrIZ (13, 14) in previous studies.

It could be argued that the densities of the DNAs of the three amoeba species were not determined on the final product but at intermediate steps in the isolation procedure, hence the densities of the DNAs in the final product 


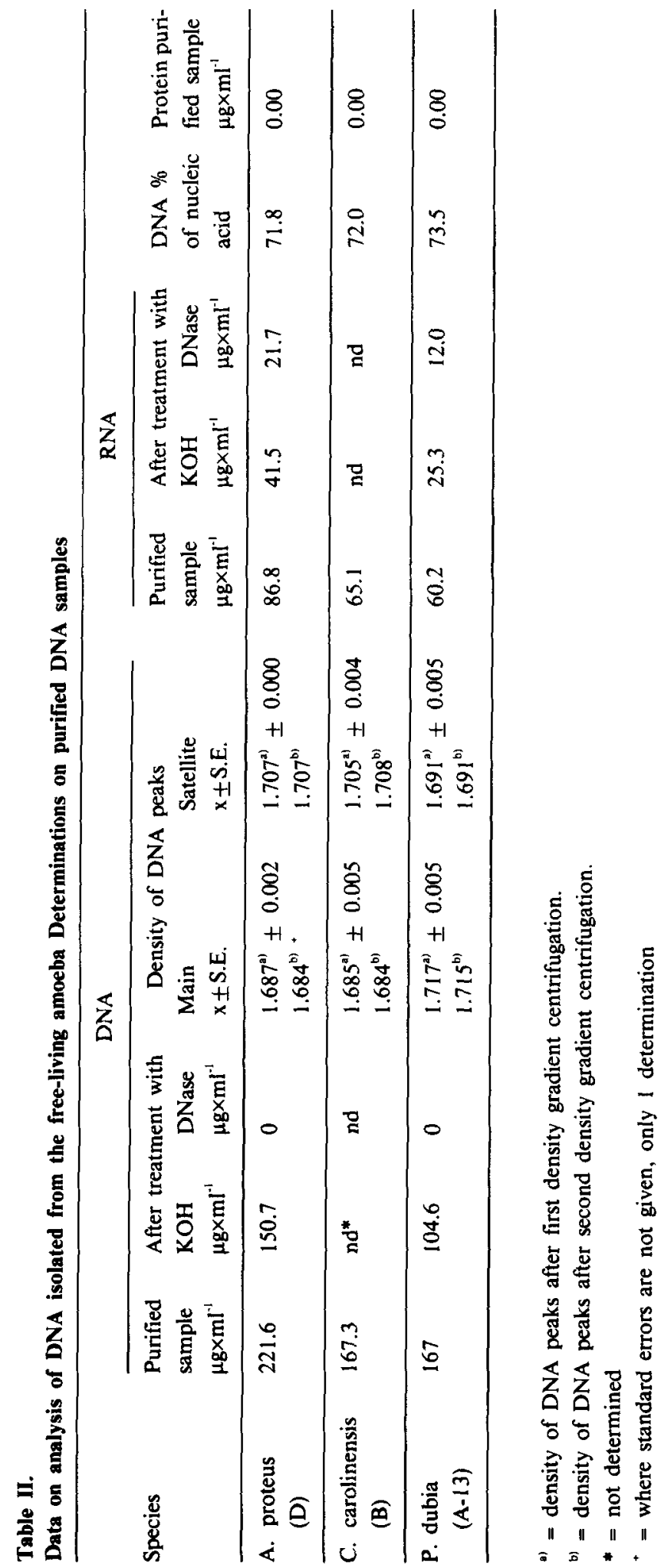


could be different than those measured. However, it should be pointed out that degraded DNA does not usually precipitate in a fibrous state with ethanol (1). Since in this study DNA did precipitate in a fibrous state, it is assumed that the final product has the same densities as the intermediate products and is a highly polymerized DNA.

The degree of contamination of the DNA preparation by RNA and protein is shown in Table II, there being approximately $26-28 \%$ RNA (\% nucleic acid) and little, if any detectable protein. The high percent of RNA, or more precisely orcinol-positive material, was unexpected since RNase treatment had been used in the first step of the isolation procedure, and this finding suggests that either RNA is so tightly bound to DNA that RNase was ineffctive or that the orcinol-positive reaction is giving a false positive for RNA.

To investigate these two possibilities in greater detail, tests were carried out using alkali liability (alkali will hydrolyze RNA but not affect DNA) and DNase treatment (DNase will hydrolyze DNA but not affect RNA). After alkali treatment, there was a $32-37 \%$ loss of DNA undoubtedly due to a loss of part of the small sample $(100 \mu \mathrm{l})$ during dialysis. However, if it is assumed that there would have also been a loss of $32-37 \%$ of RNA due to sample loss, then 1) approximately $67-70 \%$ of the orcinol-positive material remained in the final DNA preparation after $\mathrm{KOH}$ treatment and 2) approximately $31-37 \%$ of the orcinol-positive material remained in the final product after DNase treatment. This indicates that only a small amount of this material in the DNA preparation was acutally RNA.

As to nature of this non RNA, orcinol-positive material, I can only speculate since further investigations have not been carried out. However, it is known that orcinol is not just specific for pentoses, but in fact gives a positive reaction with tetroses, ketohexoses, heptuloses and hexuronic acids (5). Since the free-living amoeba contain mucopolysaccharides (10) and these complex carabohydrates are in part composed of hexuronic acids, it would seem probable that the orcinol-positive material in my DNA preparations represents structural carbohydrates such as mucopolysaccharides.
Although the above isolation procedure is complicated, much more so than those used by ADAM et al. (1), ALLEN and GibSON (3) and HONIGBERG and MOHN (15) for isolation of DNA from other protozoan species, it is very satisfactory for the isolation of genomic DNA from the free-living amoeba. With no other technique tried over the last few years (FRIZ, unpublished data) has it been possible to obtain a better yield or a purer preparation of genomic DNA from these organisms.

\section{ACKNOWLEDGEMENTS}

This report is dedicated to Professor Heinz HOLTER on the occasion of his 80th birthday. I wish to thank Professor HolTER for introducing me to the biology of the free-living amoeba and directing my scientific curiosity and interests towards biochemical studies of their taxonomy and phylogeny. Over the many years that I have studied the free-living amoeba, I also owe thanks to Dr. CiCILY CHAPMAN-ANDRESEN and mag.scient. KNUD MAX MøLLER for their help and encouragement and finally to my wife, Mrs. KIRSTEN FRIZ, for teaching me how to culture amoeba and helping with the amoeba cultures. This work was supported by grants from the Natural Science and Engineering Research Council of Canada.

\section{REFERENCES}

1. Adam, K.M.G., D.A. BlewetT \& W.C. Flamm: The DNA of Acanthamoeba spp: a method for extraction and characterization. J. Protozool. 16, 6-12 (1969).

2. Albaum. H. \& W. Umbreit: Differentiation between ribose-3-phosphate and ribose-5-phosphate by means of the orcinol-pentose reaction. J. Biol. Chem. 167, 369-376 (1947)

3. ALLEN.S.L. \& I. GibSON: The purification of DNA from the genomes of paramecium aurelia and Tetrahymena pyriformis. J. Protozool. 18, 518525 (1971)

4. Allfrey, W., A.E. Mirsky \& S. Osawa: Protein synthesis in isolated cell nuclei. J. Gen. Physiol. 40, 451-490 (1956-1957)

5. Ashwell. G.: Colorimetric analysis of sugars. In: Methods of enzymology, S.P. Colowick and N.O. Kaplan, eds., Acad. Press, New York, Vol. III pp. 73-105 (1957) 
6. Chargaff. E.: Isolation and composition of the deoxypentose nucleic acids and of the corresponding nucleoproteins. In: The Nucleic Acids, E. Chargaff and J. Davidson, eds., Acad. Press, New York, Vol. 1, pp. 307-373 (1955)

7. Cohen. A.I.: Physiological and morphological observations on amoeba. Ann. N.Y. Acad. Sci. 78, 609-622 (1959)

8. EManuel, C.F. \& I.L. ChaIKoFF: A rapid method for preparing polymerized DNA from tissues, based on separation of nuclei. Biochim. et Biophys. Acta 24, 261-266 (1957)

9. Flavell. R.A \& I.G. Jones: Mitochondrial deoxyribonucleic acid from Tetrahymena pyriformis and its kinetic complexity. Biochem. J. 116,811817 (1970)

10. FrIz. C.T: The biochemical composition of the free-living amoeba Chaos chaos, Amoeba dubia and Amoeba proteus. Comp. Biochem. Physiol. 20, $81-90(1968)$

11. FRIz.C.T.: Cation concentrations of the free-living amoeba: Amoeba proteus, Amoeaba dubia and Pelomyxa carolinensis. Comp. Biochem. Physiol. 38A, 477-482 (1971)

12. Friz. C.T.: Cesium chloride DNA density determination in field-formed preparative gradients. Arch. Protistenk. 122, 328-332 (1979)

13. FRIZ. C.T.: DNA base composition of the free-living amoeba. Biochem. Syst. Ecol. 9, 207-210 (1981)

14. FRIz.C.T.: Studies of the DNA of Amoeba proteus and Amoeba indica. Comp. Biochem. Physiol. 72B, $641-645$ (1982)

15. Honigberg, B.M. \& F.A. MOHN: An improved method for the isolation of highly polymerized native deoxyribonucleic acid from certain protozoa. J. Protozool. 20, 146-150 (1973)

16. KIRBY. K.S.: A new method for the isolation of deoxyribonucleic acids: Evidence on the nature of bonds between deoxyribonucleic acid and protein. Biochem. J. 66, 495-504 (1957)

17. LowRY, O.H. N.J.ROSEbrough.A.L. FARR \& R.J. RANDALL: Protein measurement with the Folin phenol reagent. J. Biol. Chem. 193, 265-275 (1951)

18. MANDEL, M: Nucleic acids of protozoa. In: Chemical Zoology, G.W. Kidder, ed., Acad. Press, New York, Vol. 1, The Protozoa, pp. 541-572 (1967)

19. Marmur, J: A procedure for the isolation of deoxyribonucleic acid from micro-organisms. J. Mol. Biol. 3, 208-218 (1961)

20. Mejbaum, W.: Über die Bestimmung kleiner Pentosemengen, insbesondere in Derivaten den Adeninsaure. Z. Physiol. Chem. 258, 117-120 (1939)

21. Schildkraut, C.L.. J. Marmur \& P. Doty: Determination of the base composition of deoxyribonucleic acid from its buoyant density in $\mathrm{CsCl}$. J. Mol. Biol. 4, 430-443 (1962)

22. Spear, B.B. \& D.M. Prescotr: Nuclear DNA in normal and refed Amoeba proteus. Exp. Cell Res. $130,387-392$ (1980)

23. Taurvydas, K.J.: Mass isolated amoeba nuclei. I Isolation procedure and determination of macromolecular compositionand RNA polymerase activity. Exp. Cell Res. 68, 299-308 (1971)

24. Travaglini, E. \& M.L. Metoni: Extraction and separation of nucleic acids from cesium chlorides homogenates of whole cells. Biochem. Biophys. Res. Comm. 7, 162-166 (1962) 